Article

\title{
The Secretory Apparatus of Tabernaemontana ventricosa Hochst. ex A.DC. (Apocynaceae): Laticifer Identification, Characterization and Distribution
}

\author{
Clarissa Naidoo $^{1}{ }^{(\mathbb{B}}$, Yougasphree Naidoo $^{1, *}$ and Yaser Hassan Dewir ${ }^{2,3}$ \\ 1 School of Life Sciences, University of KwaZulu-Natal, Westville Campus, Private Bag X54001, Durban 4000, \\ South Africa; naidooclarissa5@gmail.com \\ 2 Plant Production Department, P.O. Box 2460, College of Food \& Agriculture Sciences, King Saud University, \\ Riyadh 11451, Saudi Arabia; ydewir@ksu.edu.sa \\ 3 Department of Horticulture, Faculty of Agriculture, Kafrelsheikh University, Kafr El-Sheikh 33516, Egypt \\ * Correspondence: Naidooy1@ukzn.ac.za; Tel.: +27-(031)-260-7360
}

Received: 28 April 2020; Accepted: 25 May 2020; Published: 28 May 2020

check for updates

\begin{abstract}
Due to the inconsistencies in the interpretation of laticifers within the Apocynaceae, the current study aimed to distinguish, for the first time, the type and distribution of the laticifers in the embryos, seedlings and adult plants of Tabernaemontana ventricosa (Forest Toad tree). The characterization and distribution of laticifers were determined using light and electron microscopy. The findings revealed the presence of articulated anastomosing laticifers. The laticifers were found to have originated from ground meristematic and procambium cells and were randomly distributed in all ground and vascular tissue, displaying complex branching conformations. The presence of chemical constituents within the laticifers and latex determined by histochemical analysis revealed the presence of alkaloids, phenolics, neutral lipids, terpenoids, mucilage, pectin, resin acids, carboxylated polysaccharides, lipophilic, and hydrophilic substances and proteins. These secondary metabolites perform an indispensable role in preventing herbivory, hindering and deterring micro-organisms and may possibly have medicinal importance. The outcomes of the present study outlined the first micromorphology, anatomy, ultrastructural and chemical analysis of the laticifers of T. ventricosa. In addition, this investigation similarly established the probable functions of latex and laticifers.
\end{abstract}

Keywords: laticifers; latex; articulated; anastomosing; alkaloids

\section{Introduction}

The occurrence of laticifers and latex has been observed in approximately 12,500 plant species representing 22 families [1-3]. Latex is characterized as a sticky suspension of several particles containing a sap of various plant metabolites [3-5]. These naturally occurring secondary metabolites are formed from several constituents which are usually produced via primary and secondary metabolism [6,7]. Plant secondary metabolites can be divided into three chemically distinct groups: Terpenoids, phenolics, and nitrogen/sulfur containing compounds [8-10]. These diverse secondary metabolites are essential for plant growth, development, interactions, and defense systems [6-10].

Natural secondary products such as latex are comprised of a variety of composite chemical constituents which is often species dependent for, e.g., terpenoids (Hevea brasiliensis), alkaloids (Papaver somniferum), phenolic glucosides (Cannabis sativa), proteins (Ficus callosa), and tannins (Musa sp.) [11]. The occurrence of these chemical constituents could attribute to the appearance of latex as the color varies in plant species and may appear milky white, yellow, orange, red, brown, or 
even colorless $[12,13]$. Despite, the extensive occurrence of latex bearing plants in approximately $10 \%$ of flowering species, there remains insufficient information available concerning the characterization, distribution, and secretory mechanisms of laticifers in numerous plants [1-3].

Laticifers are defined as highly specialized cells (or files of cells) and have been classified into two types: The articulated type and the non-articulated type [14-17]. Articulated laticifers occur in both the primary and secondary bodies of a plant and are comprised of multiple interconnected simple cells [13-17]. These cells are distinguished as either nonanastomosing (unbranched) or anastomosing (branched) [2,3]. Whereas, non-articulated laticifers usually only arise in the primary bodies of plants, are multinucleate and develop from a single coenocytic cell $[13,14,16,18]$. These cells may display one of two forms: Unbranched vessels or branched networks [14,19].

It has been reported that non-articulated laticifers are an ancestral characteristic feature of the Apocynaceae, which often occur in all vegetative and reproductive organs of the family; however, articulated laticifers have also been observed in Tabernaemontana catharinensis [2,3,20,21]. Tabernaemontana ventricosa Hochst. ex A.DC. [22], belongs to the Apocynaceae and has a disjunctive geographical distribution in Eastern Nigeria, Ghana, the Democratic Republic of Congo, Kenya, and the northern and southern regions of South Africa [23]. The species occurs in open forests and thickets in woodlands and thrives in disturbed shady habitats [24]. In KwaZulu-Natal, the bark, stems and leaves of $T$. ventricosa are used in ethnomedicine to palliate fever, reduce high blood pressure, treat wounds and heal sore eyes [22-25]. Limited studies are available on T. ventricosa [22-25], and there are no existing reports on the morphology, anatomy, histochemistry, and ultrastructure of the laticifers of this species.

Due to the challenging interpretation and uncertainties of laticifers in Apocynaeceae, this study was carried out to describe the type and distribution of laticifers in embryos, seedlings and adult plants of T. ventricosa, as well perform a chemical analysis of the laticifers and latex to identify its probable functions.

\section{Results and Discussion}

\subsection{Leaf Micromorphology}

Stereomicrographs revealed that the leaves of T. ventricosa display a glabrous, leathery, and shiny adaxial and abaxial leaf surfaces with no prominent leaf structures (Figure 1a-d). The analysis of the leaf morphology of T. ventricosa is consistent with previous botanical observations [23]. Interestingly, there were occurrences of mite mastication on the waxy surface layer of the emergent leaves (Figure 1a-c).

Mites were observed to be embedded on the adaxial leaf surface of emergent and young leaves. There were no observations of mites being present on the adaxial surfaces of mature leaves; however, the manifestation of mites embedded on emergent leaves resulted in the formation of depressions (imprints) on the adaxial leaf surface of mature leaves (Figure 1d). According to these results, it is exceedingly probable that herbivory has a crucial effect on the development of vegetative organs and the chemical composition of $T$. ventricosa $[23,26]$. Moreover, it has been suggested that the chemical composition within leaves are altered by insect-herbivores such as mites which rapidly feeds off latex $[16,26]$, which latex is effective against chewing herbivores [26,27]. Therefore, the mites may be possibly challenged by the high concentrations of latex defense substances present within mature leaves [26-28]. This chemical defense trait plays an essential role in protecting plants against herbivore attacks $[16,26,28]$. The most probable function of laticifers is protection $[15,16,26,27]$, and this is evident in our findings on the laticifers of T. ventricosa. 

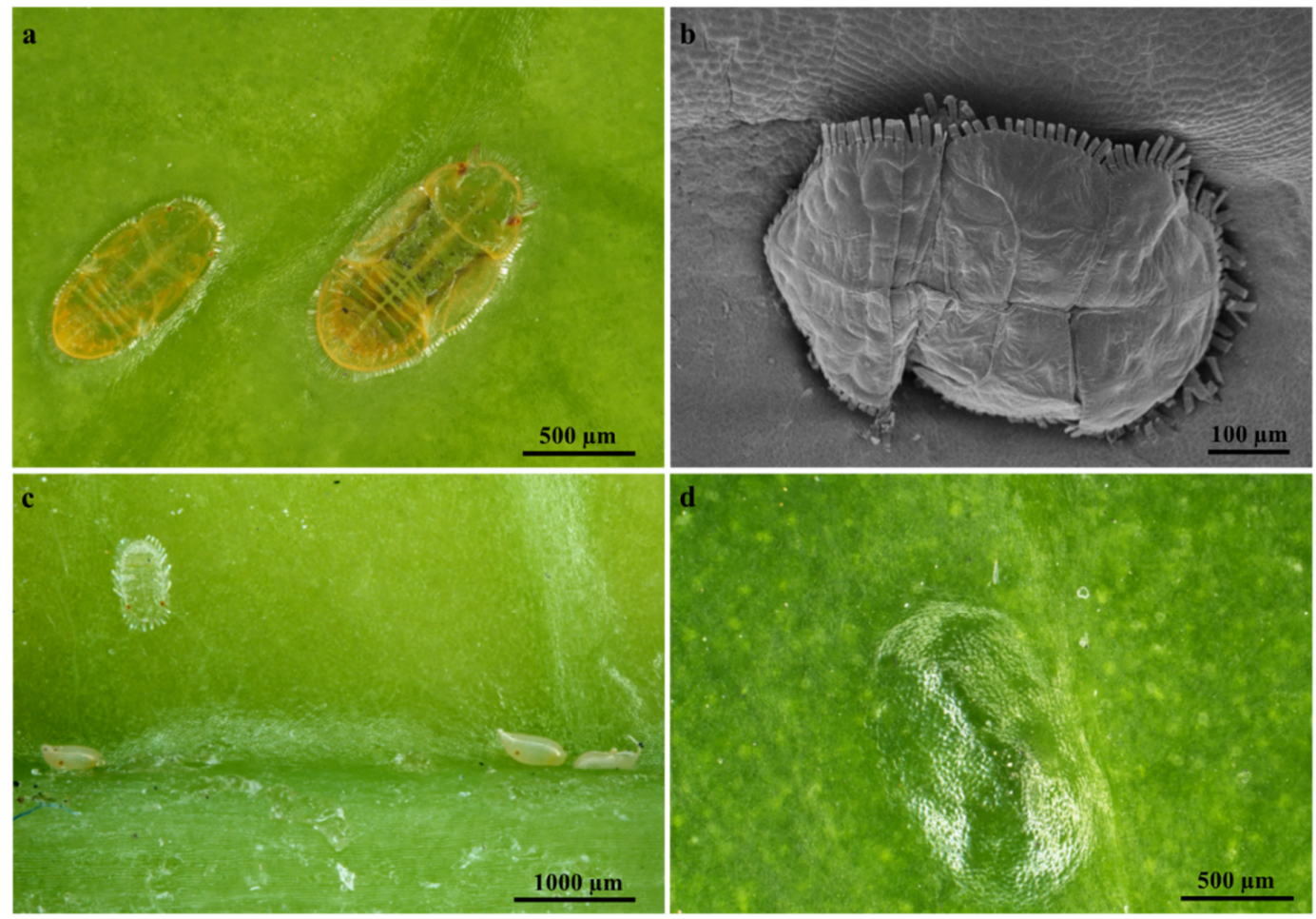

Figure 1. Micrographs showing insect-herbivore interactions on T. ventricosa adult plant leaves. (a) Mites appear embedded on the glabrous adaxial leaf surface of an emergent leaf. (b) Scanning electron microscopy micrograph showing a high-magnification image of an embedded mite on the adaxial leaf surface of an emergent leaf. (c) Stereomicrograph showing a waxy cuticle layer, an embedded mite and mite pupa on the shiny abaxial surface of a young leaf. (d) Sunken depression (Imprint from mite) present on the leathery and shiny adaxial surface of a mature leaf.

\subsection{Ontogeny and Structure of Laticifers}

The laticifers of several species within Apocynaceae are often recognized as nonarticulated; however, articulated laticifers have been observed in a few species [20,29-32]. Articulated laticifers are described as multiple interconnected simple cells, with intact or perforated transverse walls and lateral walls $[16,18,20,26]$. By analogy, the present study reports for the first time the presence of articulated anastomosing laticifers in the embryos, seedlings, and adult plants of T. ventricosa (Figures 2-4). These results are relatively confounding with previous reports $[29,30]$, and simultaneously consistent with current reports that have described the presence of articulated anastomosing laticifers in Apocynaceae [18].

The prevalence of articulated anastomosing laticifers which is novel for T. ventricosa have been classified through rigorous analyses of mature embryos and seedlings, which is recognized as an essential technique to establish the development and characterization of laticifers $[14,18,31,33]$. The analyses of embryos (Figure 2) and seedlings (Figure 3) showed that the laticifers of T. ventricosa were found to have originated from ground meristematic tissue and procambium cells. Whereas, in the adult plants the laticifers were initiated from the vascular tissue (Figure 5b), comparable to reports by Canaveze and Machado [18]. The progression of laticifers were observed to occur in the primary embryonic stages (Figure 2). These processes are simply notable due to distinctive characteristics such as thickened lateral walls, axial elongations, multinucleated spherical nucleus (Figure 2d), terminal walls (Figures $2 \mathrm{~b}, \mathrm{~d}$ and $3 \mathrm{~b}, \mathrm{c}$ ), and granular-filled protoplast (Figure 2d). In the seedlings (Figure 3c,d), lateral longitudinal laticifers are closely associated and were found to display an acute apex. According to Gama et al. (2017), these observations are the outcome of oblique sectioning of the laticifer apex [31]. Besides, there is no consistent indication of intrusive growth around the surrounding tissues of the laticifer apex (Figure 3). 
The laticifer system of T. ventricosa embryos are composed of straight and narrow laticifers (Figure 2), whereas sinuous and wide laticifers are observed in the seedling (Figure 3), the adult plant leaf blade and young stem sections (Figure 4), similarly to other studies [2,3,18,21,31-33]. The continuous branching of laticifers usually results in the formation of a network comprised of multiple laticifers that expand and connect throughout the primary and secondary bodies of the plant [31-33]. Laticifers are habitually accompanied by meristematic and adjacent cells that develop into an anastomosing complex system comprised of " $\mathrm{Y}$ ", " $\mathrm{H}^{\prime \prime}$, or " $\mathrm{U}$ "conformations [31-34]. In Figure 4a-f, distinctive branching conformations are seen, which indicate that the laticifer branching patterns in the adult leaves and stems of T. ventricosa are consistent with those observed in the genus [18,21].

\subsection{Distribution of Laticifers}

Articulated anastomosing laticifers are present in all ground and vascular tissues and are closely associated with the phloem of young and mature leaf sections (Figure 5a-c). In addition, laticifers were found scattered in the mesophyll region and often extend towards the leaf extremities (Figure 4a,c,d and Figure $7 \mathrm{a}-\mathrm{c}$ ). These results confirm previous findings on growth mode and development of laticifers in Tabernaemontana catharinensis [18,21] and Allamanda blanchetii [31]. In the stem, laticifers occur in the cambial region, cortical parenchyma, vascular tissue, and pith (Figure 6a-d). In plants laticifers often display extensive distribution patterns $[33,35,36]$. However, in some instances, the location may differ within vegetative organs, as it is assumed that the distribution patterns of laticiferous cells may possibly be species-specific and might result as a valuable tool for classification at a taxonomic level [33]. These distribution patterns are relative to those seen in the genus Tabernaemontana $[2,3,18,21,31-33]$.

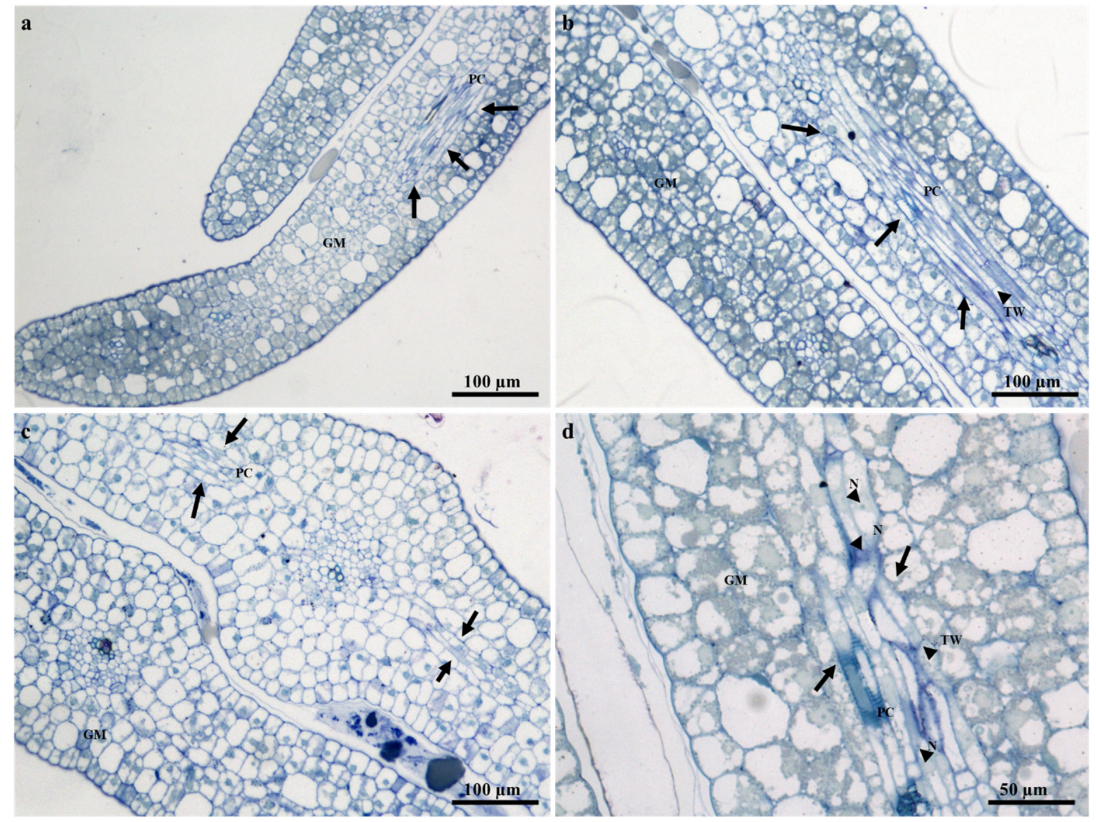

Figure 2. Light-micrographs showing the anatomy of laticifers in the mature embryos of T. ventricosa. (a) A longitudinal section through the mature embryo displaying the formation of articulated laticifers in cotyledons. (b) A longitudinal section through the mature embryo depicts the arrangement of articulated laticifers in the vascular region. Note the terminal walls within the cell. (c) A transverse section through the embryo displaying the occurrence of laticifers in the hypocotyl region. (d) A transverse section showing a highly magnified region of vascular tissue and laticifers in the hypocotyl area. Note the occurrence of terminal walls, and multinucleated laticifers Abbreviations: $\mathrm{TW}=$ terminal wall, $\mathrm{N}=$ nucleus, $\mathrm{GM}=$ ground meristem, $\mathrm{PC}=$ procambium. Arrows refer to laticifers. 

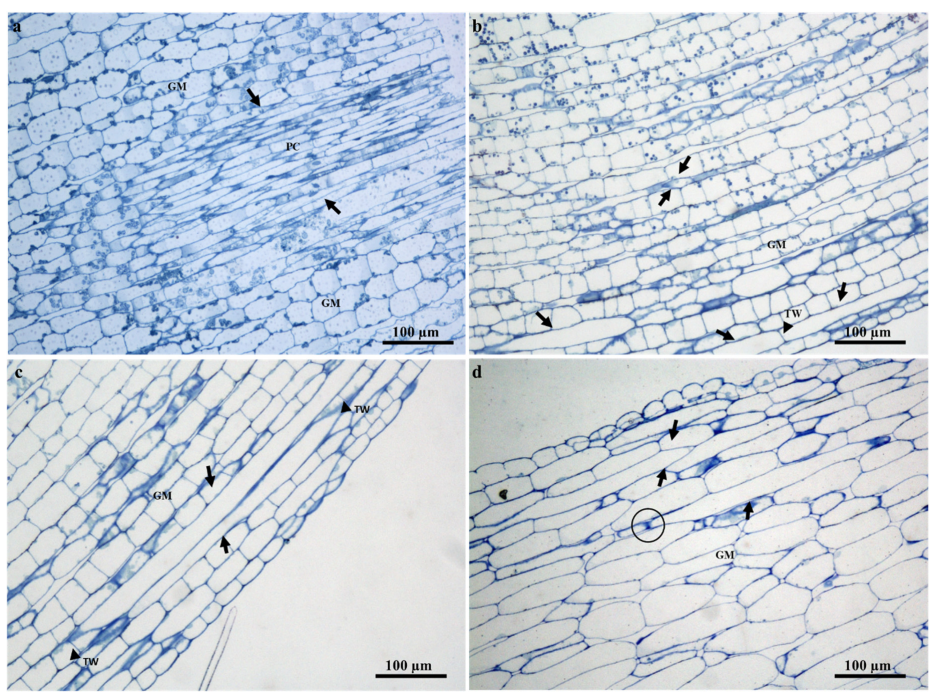

Figure 3. Light-micrographs showing the anatomy of laticifers in the seedling stem of T. ventricosa. (a) A longitudinal section through a seedling stem displaying the occurrence of articulated anastomosing laticifers. (b) A longitudinal section through the stem of a seedling depicts the arrangement of articulated laticifers closely associated with the epidermal tissue. (c) A transverse section through the seedling stem displaying an elongated-tapered syncytia cell, with terminal walls at the lateral ends. (d) A transverse section through the seedling stem showing the arrangement of overlapping laticifers. Note the cell wall dissolution of terminal walls at the tapered regions. Abbreviations: TW = terminal wall, GM = ground meristem, $\mathrm{PC}=$ procambium. Arrows refer to laticifers. Circle depicts cell wall dissolution.

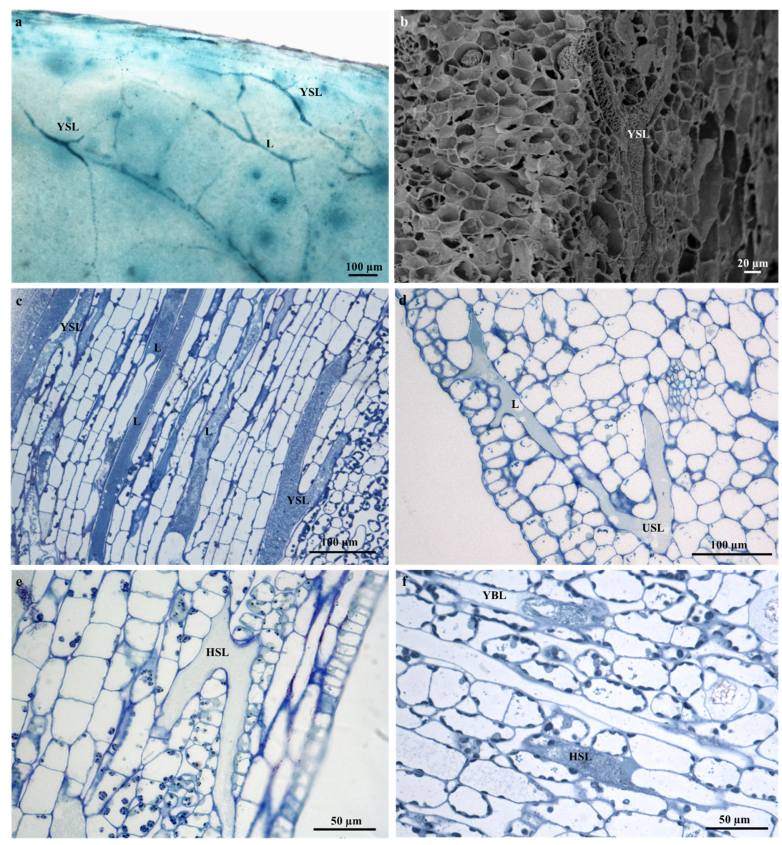

Figure 4. Articulated anastomosing laticifers of T. ventricosa. (a) Light micrograph of a whole stained seedling leaf showing a branched network of Y-shaped laticifers. (b) Scanning electron microscopy micrograph of a young stem fracture showing a single Y-shaped branched laticifer. (c) Light micrograph of sequential sectioned young leaf showing Y-shaped laticifers (d) Light micrograph of an emergent leaf section showing a branching laticifer and a U-shaped branched laticifer. (e) Light micrograph of a young stem section displaying a branched $\mathrm{H}$-shaped laticifer. (f) Light micrograph of a young stem section depicts branched $\mathrm{Y}$ - and H-shaped laticifers. Abbreviations: L = laticifer, USL = U-shaped laticifer, YSL = Y-shaped laticifer, HSL = H-shaped laticifer. 


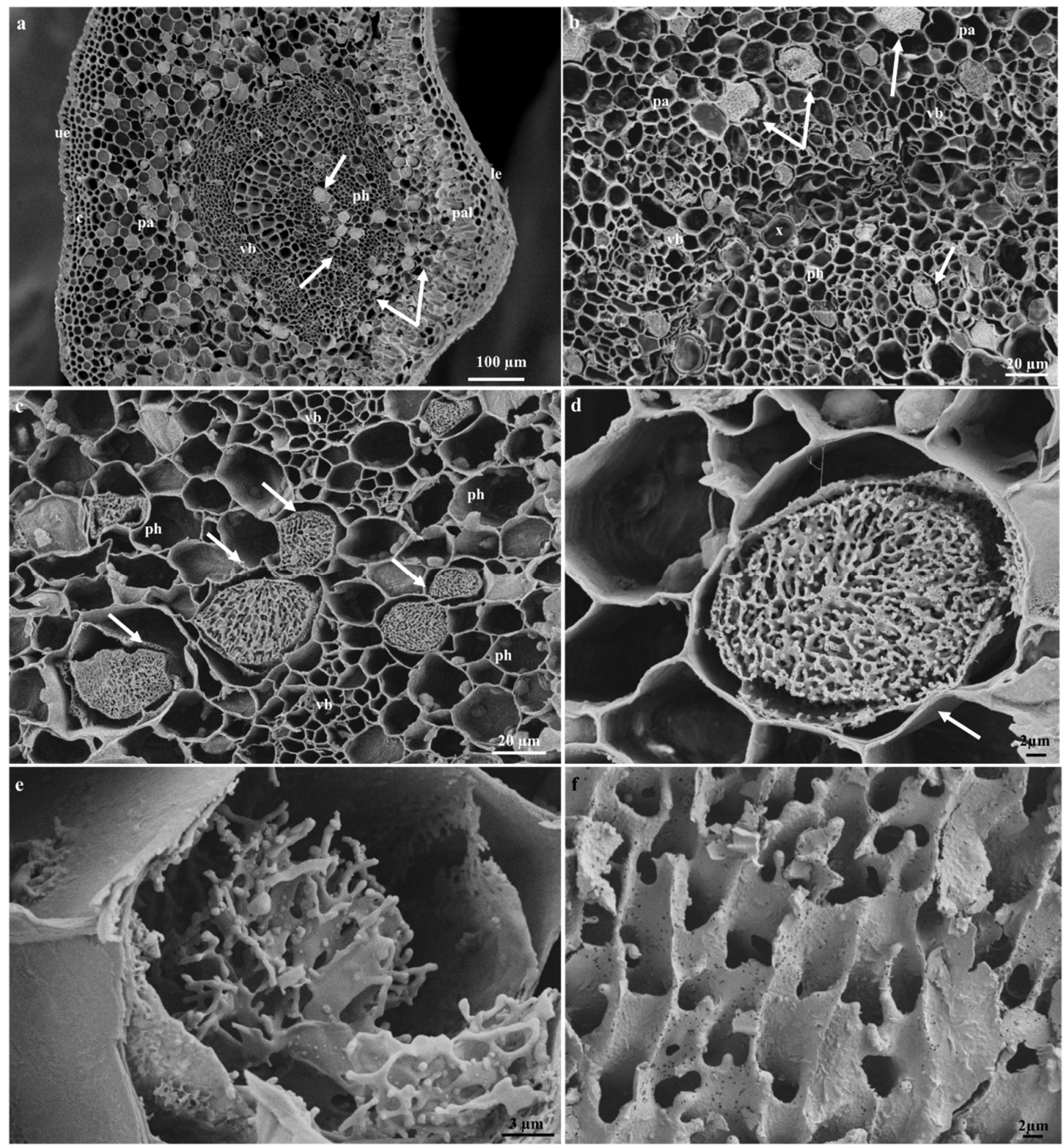

Figure 5. Scanning electron microscopy micrographs showing freeze-fractures of the adult leaves of T. ventricosa. (a) Low-magnification SEM micrograph showing a freeze-fracture of the midrib from a young leaf. (b) Freeze-fracture showing the distribution of laticiferous cells along the vascular bundles and phloem of a mature leaf midrib. (c) Laticifer cell distribution among vascular bundles of a young leaf midrib. (d) Laticifer cell showing latex exudate from a young leaf. (e) Latex exudate within laticifer cell from a young leaf. (f) High-magnification image showing the appearance of latex exudate from an emergent leaf. Abbreviations: $u e=$ upper epidermis, $c=$ collenchyma, $p a=$ parenchyma, $\mathrm{vb}=$ vascular bundles, $\mathrm{ph}=$ phloem, $\mathrm{x}=$ xylem, $\mathrm{pal}=$ palisade, $\mathrm{le}=$ lower epidermis. Arrows refer to laticifer. 


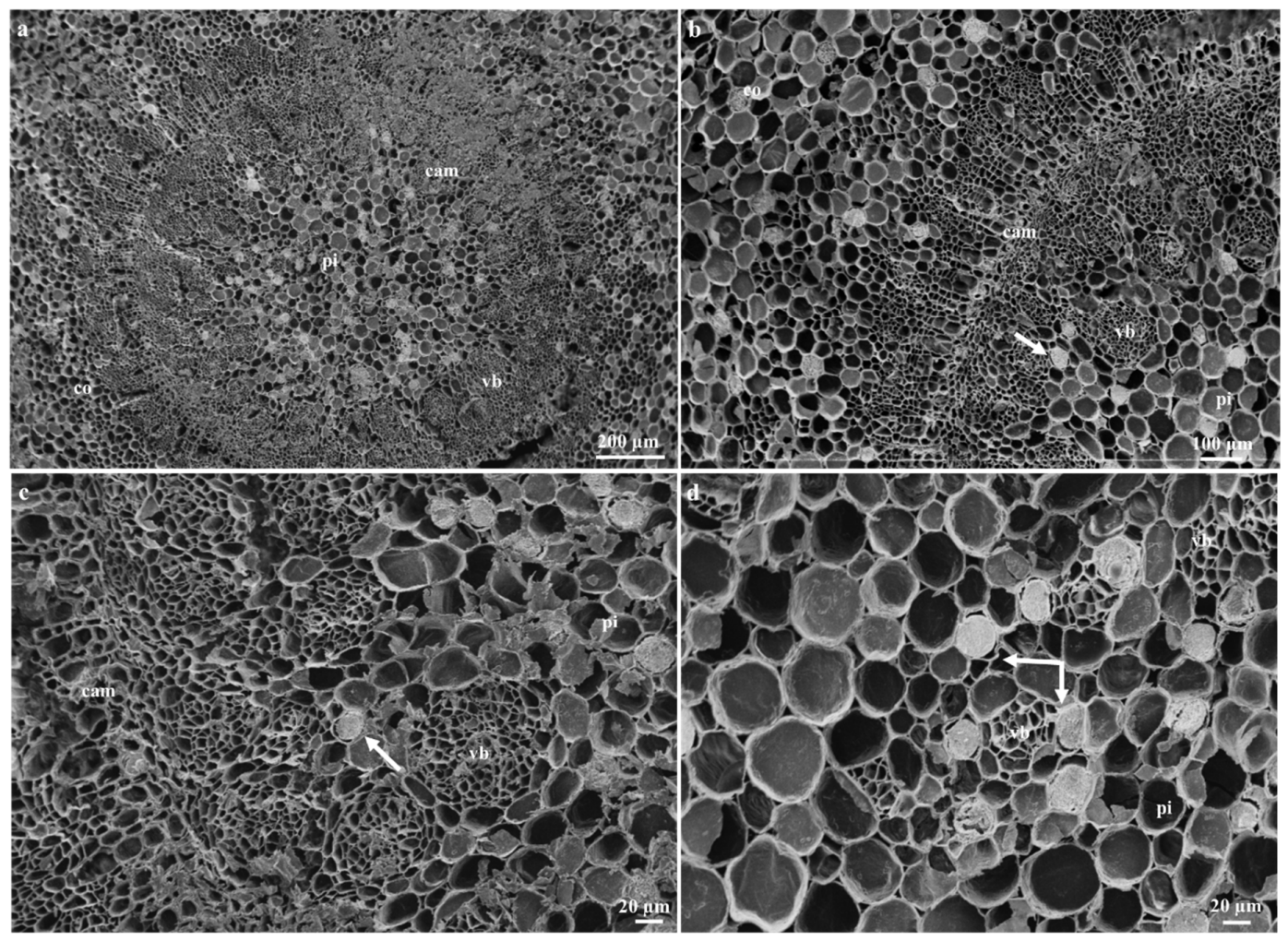

Figure 6. Scanning electron microscopy micrographs showing freeze-fractures of adult stems of T. ventricosa. (a) Low-magnification SEM micrograph showing the distribution of laticifers in a freeze-fracture of a young stem. (b) Freeze-fracture of a young stem depicts the arrangement of laticiferous cells along the vascular cambium. (c) Laticifer cell distribution among vascular bundles of a young stem. (d) High-magnification image showing appearance of laticifer and latex exudate from a young stem. Abbreviations $\mathrm{vb}=$ vascular bundles, $c a m=$ cambium, $c o=$ cortex, $\mathrm{pi}=$ pith . Arrows refer to laticifer. Arrows refer to laticifers.

\subsection{Laticifer Histochemical Characterization}

The milky white latex of T. ventricosa is a synapomorphy of the Apocynaceae [13,37-39]. Considering the composite secretion of latex which is often comprised of a variety of specialized metabolites, several latex bearing plants are well-known for their specific substances $[29,33,40,41]$. The histochemical analysis of the laticifers and latex within the vegetative organs of $T$. ventricosa revealed for the first time in this species the presence of carboxylated polysaccharides (Figures 7a and 8a), lipophilic and hydrophilic substances (Figures $7 \mathrm{~b}$ and $8 \mathrm{~b}$ ), proteins (Figures $7 \mathrm{i}$ and 81 ), phenolics (Figures $7 \mathrm{e}$ and $8 \mathrm{i}$ ), terpenoids (Figures $7 \mathrm{~d}$ and $8 \mathrm{~d}$ ), neutral lipids (Figures $7 \mathrm{~g}$ and $8 \mathrm{~h}$ ), alkaloids (Figures $7 \mathrm{j}$ and $8 \mathrm{e}$ ), mucilage and pectin (Figures $7 \mathrm{k}$ and $8 \mathrm{f}$ ), resin acids (Figures $7 \mathrm{f}$ and $8 \mathrm{~g}$ ), and acidic substances (Figures 71 and $8 \mathrm{j}$ ). These findings are consistent with previous studies, as the compounds within the laticifers and latex were previously detected in species belonging to the genus Tabernaemontana and may be of therapeutic and pharmacological importance [42-47]. Furthermore, regarding the chemical constituents detected within leaf and stem sections of T. ventricosa, studies have shown a possible association between the secondary metabolites of latex and defense mechanisms against pathogens and herbivores $[13,15,16,20,27,48,49]$. The latex (Figure $5 d-f$ ) found within the laticifers of T. ventricosa contains chemical compounds (Figures 7a-l and 8a-1), which may be lethal or function as a preventative towards herbivores and pathogens and most likely hinder micro-organism proliferation $[13,16,26,27,33,46]$.

A positive and intense color reaction for alkaloids using Wagner's and Dittmar's reagents was observed in the laticifer protoplast of the vegetative organs (Figures $7 \mathrm{j}$ and $8 \mathrm{e}$ ). These results are consistent with the first phytochemical investigation performed on T. ventricosa as major alkaloidal 
components namely, 10-hydroxyheyneanine and akuammicine were detected and isolated from the leaves and stembark [46]. According to the results of the current study, the traditional usage of the plant may possibly be related to the high presence of alkaloids, which is often used for the treatment of various ailments such as high fever, pain, and exposed wounds [23,25]. Moreover, previous reports on Tabernaemontana species showed that the alkaloids dregamine and voacangine isolated from T. elegans and indole alkaloids found in T. catharinensis exhibited substantial anti-bacterial activity and have medicinal value $[47,50]$. It has been observed that plants within the genus Tabernaemontana often obtain a profusely high alkaloid content, usually displaying biological activity [42,45]. According to Van Beek et al. (1984), alkaloids are organic nitrogenous compounds with the nitrogen being either in its primary, secondary, or tertiary form [43]. Additionally, monoterpene indole and bisindole alkaloids are the major classes of alkaloids within the Tabernaemontana genus, other compounds include terpenes, lactones, steroids, phenolics, and flavonoids [42-45]. A few of the latter compounds, namely alkaloids (Figures 7j and 8e), terpenoids (Figures 7d and 8d) and phenolics (Figures 7e and 8i) have been observed in the current study.

\section{Laticifer Fluorescence Microscopy}

Preliminary observations with autofluorescence revealed the presence of plastids indicated by a red fluorescence and phenolics which displayed a high-intensity blue fluorescence color within the laticifer cells (latex) of vegetative organs (Figure 9a,b). Phenols have been reported to contain anti-oxidant, anti-inflammatory, and anti-bacterial properties [45,51]. A few of the cell walls of laticifers stained with Acridine orange in leaf sections (Figure 9c) displayed a yellow-green fluorescence; however, many laticifer cell walls in the leaf and stem sections (Figure 9c,d) also displayed a uniform red-orange coloration of high intensities. Lignified tissues are distinguished by a yellow-green fluorescence, whilst non-lignified tissue exhibits an orange-red fluorescence [52]. Calcofluor white staining depicted high concentrations of cellulose in laticifer walls [52], as these cells were observed to produce an intense blue color (Figure 9e,f). The composition of cell walls was examined in all histochemical and fluorescence tests to differentiate between neighboring cells and laticifers. These observations were based on cell thickness and composition of laticifer cell walls as standard measures [52].

\subsection{Laticifer Ultrastructure of Adult Plant Leaves}

Due to the difficulty experienced in the ultrastructural analyses of embryos, seedlings, and adult stems, only young leaf material was used for ultrastructural investigations. The laticifer system in the young leaves of T. ventricosa was formed by the accumulation of new cells, accompanied by a rapid discontinuity of transverse cell walls, resulting in the combination of their protoplasts (Figure 10). These ultrastructural changes have been similarly observed in other latex bearing species $[18,31,33]$. These cells were notable from surrounding ground and vascular tissue by contact with adjacent cells via cell wall dissolution (Figure 10c), irregularly thickened cell walls (Figure 10e), latex content (Figures 10c and 11c,d) and their lengthened form (Figure 11a), similarly observed in other studies [18,31]. Irregularly shaped laticifers displaying acuminate ends (acute apex) were found appressed to the middle lamella of adjacent cells indicative of an oblique section of the apical cell as observed in Figure 10a [31]. With the analyses of the terminal walls of laticifers, it is possible to observe the expansion of laticifers via the dissolution of its cell walls and the concurrent accumulation of new cells to the existing laticifers, which has been observed in T. catharinensis (Figure 10a,c) [18,41]. The rapid cell wall dissolution of laticifers usually occurs from the center towards the periphery of the cell (Figure 10c) [41]. This process is achieved by small lytic vesicles formed from the peripheral endoplasmic reticulum $[18,31,41]$. Subsequently, the plasma membrane and tonoplast of both cells merge resulting in the formation of a continuous laticifer with one central vacuole [31,41].

Golgi bodies and dictyosomes were observed embedded within the cell (Figure 10e,f), with small vacuoles in proximity (Figure 11a). It has been suggested that these smaller vacuoles are the initial forms of a central vacuole and possibly contribute to the abundance of vesicles [18,31,53]. The formation 
of small vacuoles is due to the endoplasmic reticulum and electron dense material observed in the cytoplasm (Figure 10c). Initial subcellular alterations of the cytoplasm are due to the combination of tiny highly vacuolated cells (Figure $11 \mathrm{a}-\mathrm{c}$ ), that result in the establishment of a large central vacuole within a cell $[18,31,41]$. The increased size of the central vacuole was found to compress the cytoplasm into a thin parietal layer, likewise to literature [31]. At this stage of latex production, the contents of the cell are altered significantly [18,31], as an abundance of mitochondria (Figure 11b,c), lipid bodies (Figure 10b), osmiophilic bodies (Figures 10b-d and 11b), plastids and starch grains are observed (Figure 10a,d). The occurrence of plentiful mitochondria is possibly associated with the supply and demand of energy required by the secretory process of the variable components of latex [31,54]. At the initiation of the secretory process, osmiophilic bodies are produced and relocated to the central vacuole. This process has been observed in Calotropis gigantea [55].

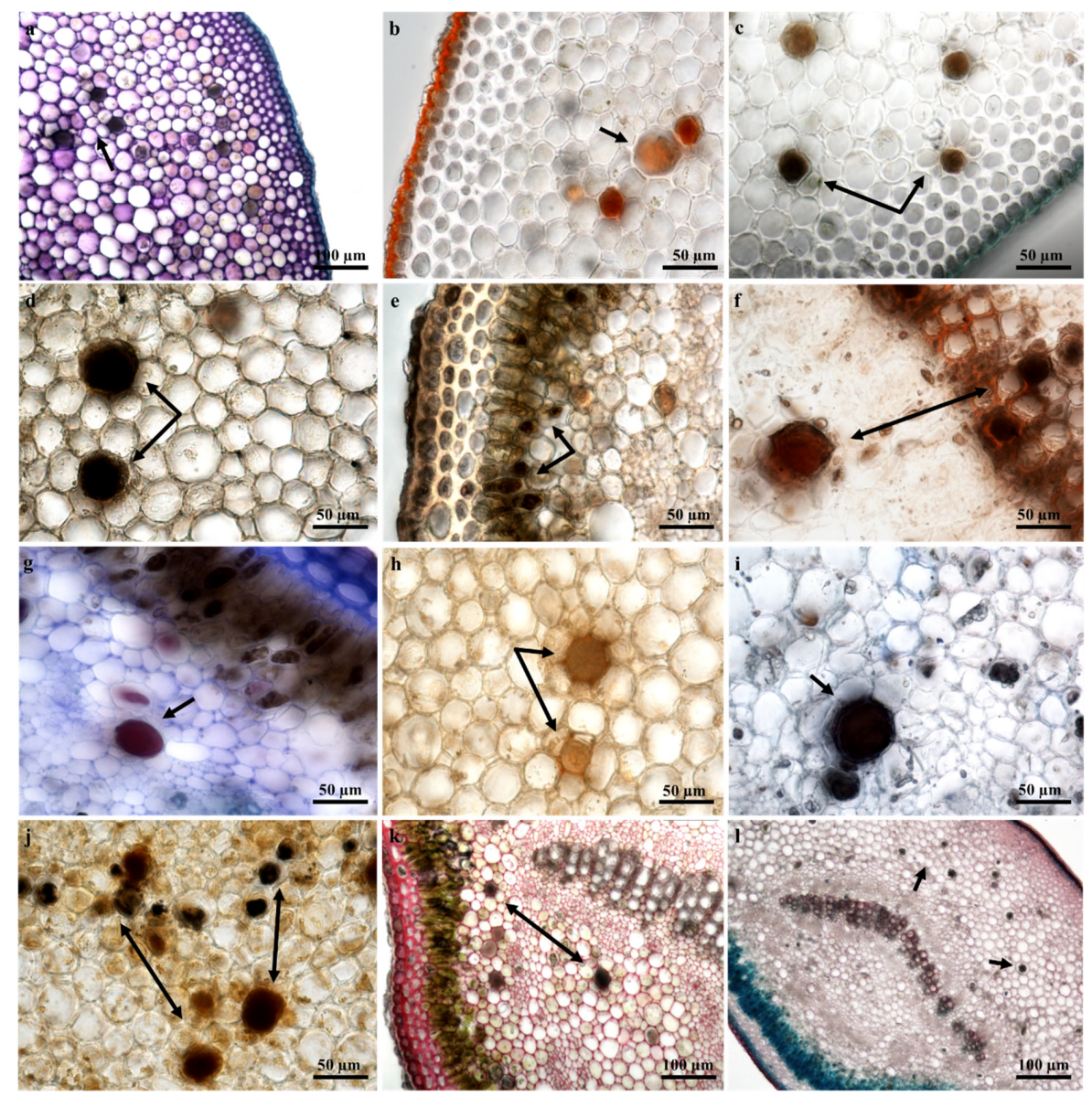

Figure 7. Histochemical observations of laticifers in young leaf midrib sections of T. ventricosa. (a) Presence of polysaccharides within laticifer cells stained using Toluidine Blue. (b) Positive staining of lipids within laticifers using Sudan IV. (c) Negative staining of lipids, cutin, and suberized cell walls of laticifers using Sudan black B. (d) Ferric Trichloride positively stained laticifers a dark-black color. (e) Presence of phenolics within laticifer cells stained using Ferric Chloride. (f) Intense staining of resin acids within laticifers using NADI reagent. (g) Intense staining of neutral lipids within laticifers using Nile Blue. (h) Negative staining of lignin aldehydes within laticifer and cell components stained using Phloroglucinol. (i) Intense blue-black staining of proteins in laticifers. (j) Intense staining of alkaloids within laticifers stained using Wagner's and Dittmar's reagent. (k) Positive staining of mucilage and pectin using Ruthenium Red. (1) Presence of acidic substances in laticifers stained using Safranin and Fast Green. Arrows refer to laticifer. 

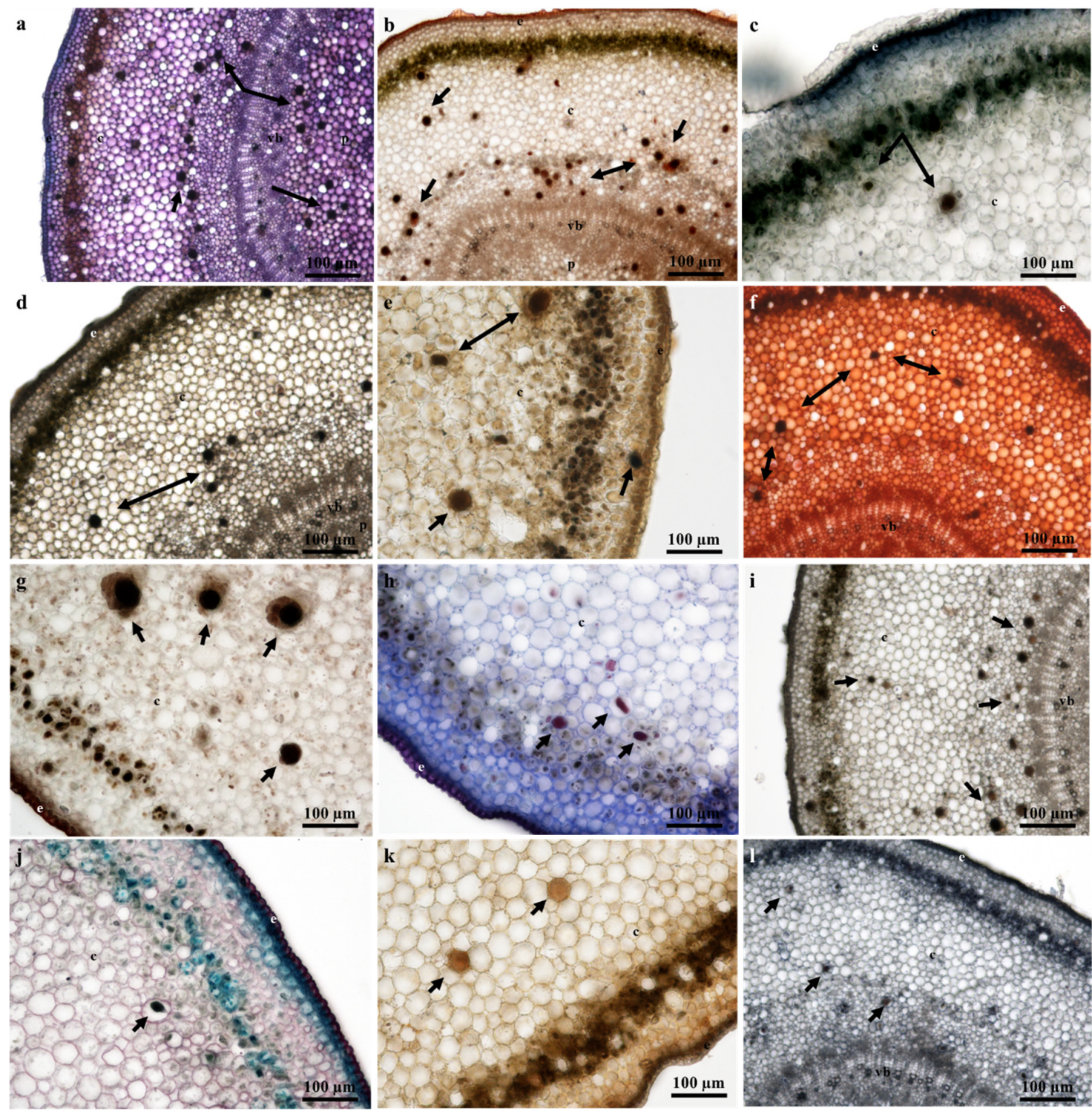

Figure 8. Histochemical observations of laticifers in young stem sections of T. ventricosa. (a) Presence of polysaccharides in laticifers stained using Toluidine Blue. (b) Lipids stained using Sudan IV. (c) Negative staining of lipids using Sudan Black B. (d) Ferric Trichloride positively stained laticifers a dark-black color. (e) Alkaloids identified within laticifers using Wagner's and Dittmar's reagent. (f) Detection of mucilage and pectin using Ruthenium Red. (g) Intense staining of resin acids in laticifers using NADI reagent. (h) Neutral lipids in laticifer identified using Nile Blue. (i) Detection of phenolics within laticifer stained using Ferric Chloride. (j) Presence of acidic substances within laticifers stained using Safranin and Fast Green. (k) Negative staining of lignin aldehydes using Phloroglucinol. (1) Proteins detected in laticifers. Arrows refer to laticifer.

The latex that fills the laticifer lumen is regarded as the protoplast of the laticifer $[41,56]$ and contains an emulsion of latex containing rubber particles within the parietal cytoplasm (Figure 11d). Furthermore, a rupture (natural or induced) of the laticifer cell wall results in the release of its latex contents, which is often used as protective mechanism by latex-bearing plants $[26,27]$. 


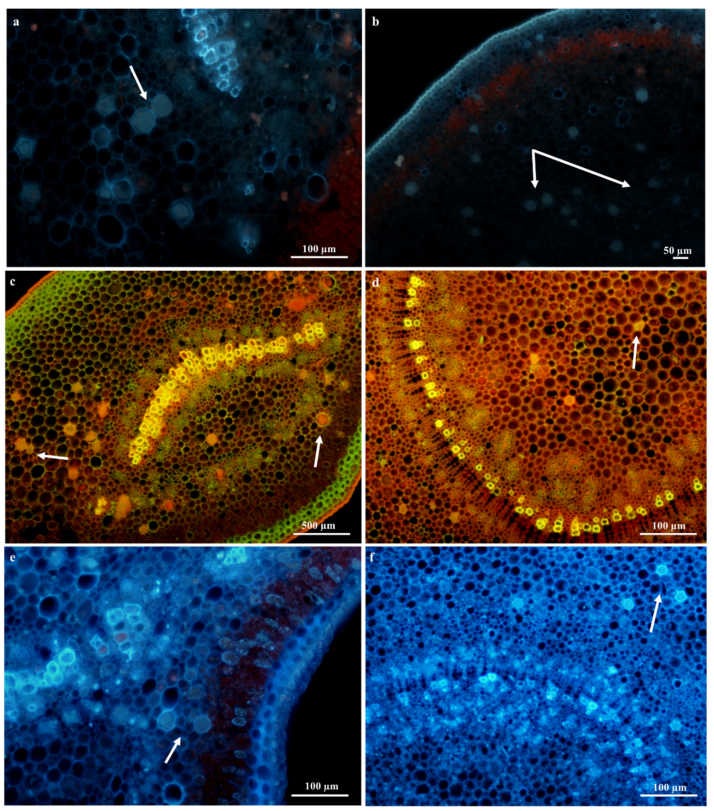

Figure 9. Fluorescence microscopy of young leaf midrib and young stem sections of T. ventricosa. (a) Auto-fluorescence of laticifer cell in leaf section showing intense blue fluorescence indicating the presence of phenolics. (b) Positive auto-fluorescence stain of stem section indicative of phenolics. $(\mathbf{c}, \mathbf{d})$ Leaf and stem sections stained orange-red using Acridine Orange indicating non-lignified laticifer contents. (e,f) Positive staining for cellulose using Calcofluor White on leaf and stem sections. Arrows refer to laticifer.

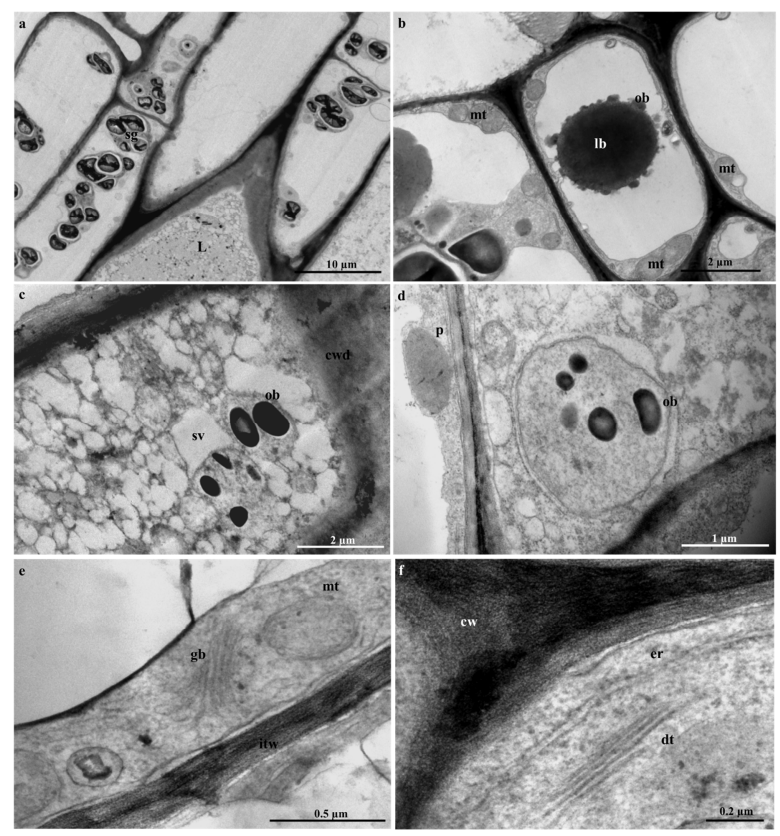

Figure 10. Ultrastructure of laticifers in the adult leaves of T. ventricosa. (a) Oblique section of a laticifer cell showing an acute apex and starch grains. (b) Lipid body closely associated with osmiophilic bodies. (c) Coalescence of small vacuole with granular laticifer cell content. (d) Osmiophilic bodies free in the cytosol and plastid with an electron-dense globule. (e) Presence of mitochondria, Golgi body and irregular thickening of cell walls. (f) Expansion of endoplasmic reticulum and presence of dictyosomes nearby the cell wall. Abbreviations: $\mathrm{L}=$ Laticifer, $\mathrm{sg}=$ starch grain, $\mathrm{cwd}=$ cell wall dissolution, $\mathrm{sv}=\mathrm{small}$ vacuole, $\mathrm{ob}=$ osmiophilic bodies, $\mathrm{p}=$ plastid, $\mathrm{gb}=$ golgi body, $\mathrm{mt}=$ mitochondria, $\mathrm{itw}=$ irregular thickened walls, $\mathrm{er}=$ endoplasmic reticulum, $\mathrm{dt}=$ dictyosomes, $\mathrm{cw}=$ cell wall, $\mathrm{lb}=$ lipid body. 


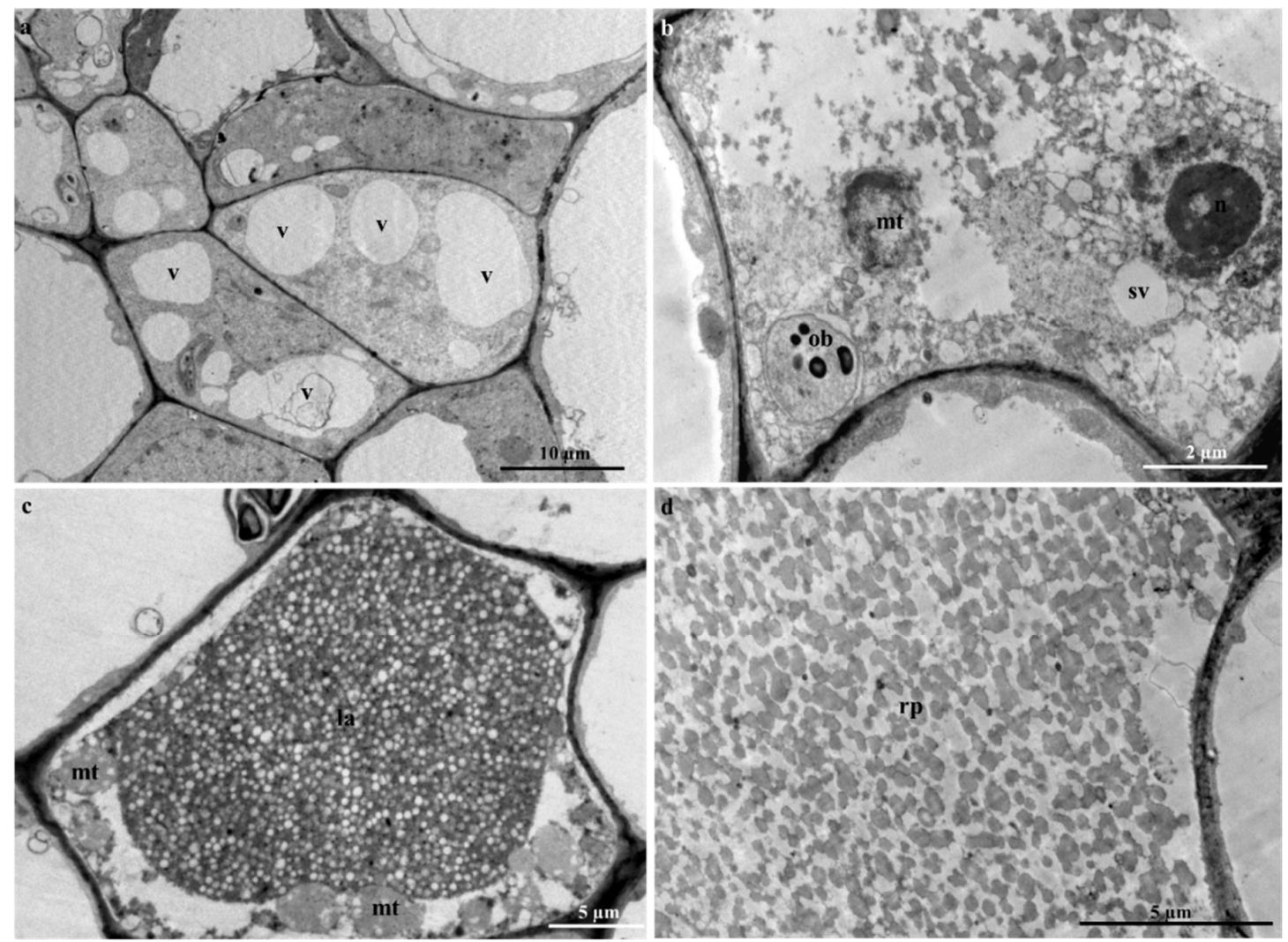

Figure 11. Latex production in adult leaves of T. ventricosa. (a) Highly vacuolated cytoplasm of young laticifer. (b) Initiation of secretory activity. (c) Latex metabolites forming an emulsion within the central vacuole of the laticifer cell. (d) Rubber particles within the latex emulsion. Abbreviations: $\mathrm{v}=$ vacuole, $\mathrm{ob}=$ osmiophilic bodies, $\mathrm{mt}=$ mitochondria, $\mathrm{n}=$ nucleus, $\mathrm{sv}=$ small vacuole, $\mathrm{la}=$ latex, rp $=$ rubber particle.

\section{Materials and Methods}

\subsection{Collection of Leaf and Stem Samples}

Fully grown and adult $(\sim 12-15 \mathrm{~m}) T$. ventricosa plants of wild origin were collected from the University of KwaZulu-Natal (Westville campus), South Africa (1). $29^{\circ} 49^{\prime} 03.3^{\prime \prime} \mathrm{S} 30^{\circ} 56^{\prime} 32.7^{\prime \prime} \mathrm{E}$; (2). $29^{\circ} 49^{\prime} 02.5^{\prime \prime} \mathrm{S} 30^{\circ} 56^{\prime} 32.5^{\prime \prime} \mathrm{E}$; (3). 3.29 $49^{\prime} 04.6^{\prime \prime} \mathrm{S} 30^{\circ} 56^{\prime} 43.9^{\prime \prime} \mathrm{E}$, from February 2017 to October 2018. Approximately three plants of T. ventricosa were sampled for analysis, with the leaves and stems sampled in triplicates, for each plant. The plant material was taxonomically identified and a voucher specimen (18222) was deposited at the Ward herbarium, School of Life Sciences, University of KwaZulu-Natal. The leaves were classified into three different developmental stages namely, emergent $(<10 \mathrm{~mm})$, young $(10-60 \mathrm{~mm})$, and mature $(>60 \mathrm{~mm})$. For the purpose of stem analysis, only young stems were used, as mature stems were hardy and problematic for further examination. In addition, mature embryos and seedling stems of $T$. ventricosa were also studied. These specimens were acquired, by the collection of seeds from mature fruits of T. ventricosa growing in a sloped area $\left(29^{\circ} 49^{\prime} 03.3^{\prime \prime} \mathrm{S} 30^{\circ} 56^{\prime} 32.7^{\prime \prime} \mathrm{E}\right)$ during 2017 and 2018. Seeds $(n=32)$ of T. ventricosa were carefully nicked $(0.1 \mathrm{~cm})$ using a sterile blade and soaked for approximately $48 \mathrm{~h}$ in distilled water [18]. Then, embryos were isolated from soaked seeds $(n=16)$. To obtain $T$. ventricosa seedlings, seeds $(n=16)$ were cultivated into trays containing vermiculite and maintained in a growth chamber under controlled light ( $12 \mathrm{~h}$ photoperiod) and air temperature $\left(24^{\circ} \mathrm{C}\right)$. The trays were watered regularly till seedlings emergence. After 20 days, the seedlings displayed two cotyledons, a stem $(3 \mathrm{~cm})$ and a main root $(4 \mathrm{~cm})$. 


\subsection{Stereomicroscopy}

Fresh emergent, young and mature leaf samples were used to analyze the adaxial and abaxial surfaces. Images were obtained using NIS-Elements D software on the Nikon AZ100 stereomicroscope equipped with a Nikon fiber Illuminator (Nikon, Tokyo, Japan).

\subsection{Scanning Electron Microscopy (SEM)}

\subsubsection{Chemical Fixation}

Young and mature leaves, and young stems of T. ventricosa were hand sectioned $\left( \pm 5 \mathrm{~mm}^{2}\right)$ and fixed for $24 \mathrm{~h}$ in $2.5 \%$ glutaraldehyde. The sections were washed with $0.1 \mathrm{M}$ phosphate buffer ( $\mathrm{pH} 7.2)$ and post-fixed in $0.5 \%$ osmium tetroxide for $2 \mathrm{~h}$. Thereafter, the samples were washed with $0.1 \mathrm{M}$ phosphate buffer and subjected to dehydration by graded concentrations of ethanol $(30 \%, 50 \%, 75 \%$, and $100 \%$ ). The sections were mounted onto aluminum, stubs using double-sided adhesive carbon tape and then critically point-dried using a Quorum K850 Critical Point Dryer, and sputter-coated with gold in a Quorum Q150 RES sputter coater. Samples were viewed with a scanning electron microscope Zeiss LEO 1450 at a working distance of $14-17 \mathrm{~mm}(5.00 \mathrm{kV})$. Images were captured using SmartSEM image software.

\subsubsection{Freeze-Fracture}

Fresh young leaves and stems were trimmed $\left( \pm 5 \mathrm{~mm}^{2}\right)$ and were quenched in liquid nitrogen slush $\left(-210^{\circ} \mathrm{C}\right)$, thereafter the sections were manually fractured using a blade. The fractured samples were freeze-dried in an Edward's Modulyo EPTD3 freeze-drier for $72 \mathrm{~h}$. The freeze-dried samples were mounted onto aluminum stubs using carbon adhesive tape and the stubs were coated with gold in a Quorum 150 RES sputter coater. The samples were then analyzed using Smart SEM imaging software on the LEO 1450 (Zeiss) scanning electron microscope at a working distance of 14-17 mm $(5.00 \mathrm{kV})$.

\subsection{Transmission Electron Microscopy (TEM)}

Fresh young leaf and stem sections (adult plant), embryos, and the seedling stems $\left( \pm 2 \mathrm{~mm}^{2}\right)$ were fixed in $2.5 \%$ glutaraldehyde for $24 \mathrm{~h}$. The sections were washed with $0.1 \mathrm{M}$ phosphate buffer ( $\mathrm{pH}$ 7.2), followed by post-fixation with $0.5 \%$ osmium tetroxide for $4 \mathrm{~h}$. Thereafter, the samples were washed with $0.1 \mathrm{M}$ phosphate buffer and dehydrated sequentially in $30 \%, 50 \%, 75 \%$, and $100 \%$ acetone. The dehydrated samples were infiltrated with $25 \%, 50 \%$, and $75 \%$ of a Spurr's resin and acetone mixture for $12 \mathrm{~h}$, respectively. Thereafter, the samples were infiltrated in 100\% resin for $24 \mathrm{~h}$ and then embedded in $100 \%$ resin using silicone molds and polymerized at $70{ }^{\circ} \mathrm{C}$ in an oven for $8 \mathrm{~h}$.

The resin block samples containing leaf and stem sections, embryos and seedling stems were sectioned using the Leica EM UC7 ultra-microtome equipped with a glass knife that was processed using a Glass Knife Maker LKB 7801A. Serial survey sections $(0.5-1 \mu \mathrm{m})$ containing leaf and stem sections, embryos and seedling stems, respectively were placed onto slides, stained with Toluidine Blue and analyzed using NIS-Elements D imaging software on the Nikon Eclipse 80i light compound microscope (Nikon, Japan). The areas of interest were observed using serial survey sections, thereafter, ultrathin leaf sections $(100 \mathrm{~nm})$ were cut and picked up using copper grids. Prior to viewing, the copper grids were stained by placing the sections on a large drop of $2.5 \%$ uranyl acetate. The sections were stained for $10 \mathrm{~min}$ at $23^{\circ} \mathrm{C}$ and rinsed with fresh distilled water. The copper grids were then placed onto drops of lead citrate in a closed glass Petri dish with dry $\mathrm{NaOH}$ pellets (avoids build-up of moisture which causes the stain to precipitate). The copper grids were stained for $10 \mathrm{~min}$, rinsed with distilled water and placed on filter paper to dry. The sections were analyzed, and images were captured using a $100 \mathrm{kV}$ JEOL 1010 transmission electron microscope equipped with iTEM software (JEOL, Peabody, MA, USA). 


\subsection{Histochemistry}

Fresh young and mature leaves, and young stems were used to obtain semi-thin sections $(80-100 \mu \mathrm{m})$ for histochemical analysis. The material was sectioned using the Oxford ${ }^{\circledR}$ Vibratome sectioning system and the sections were stained with the following reagents to detect the presence and localization of chemical compounds. Toluidine Blue was used to test for the presence of carboxylated polysaccharides, phosphate groups, and polyphenols [57]. The presence of lipids was detected with Sudan IV and Sudan Black B [52]. Lignin aldehydes and cuticle components were detected with Phloroglucinol [52]. Phenolic compounds and terpenoids were tested using Ferric chloride and Ferric trichoride [52,58]. Ruthenium red was used to test for the presence of mucilage and pectin [52]. Nile blue was used to detect neutral and acidic lipids [52]. Proteins, essential oils, and resin acids were tested using Mercuric bromophenol blue [59] and NADI reagent [52], respectively, Alkaloids were detected using Wagner's and Dittmar's reagent [60]. Acidic components were detected using a double stain technique comprised of safranin and fast green [61]. Each test was carried out in triplicates (3 leaves and stems were sectioned, and 3 sections were used from each sample) and stained sections were analyzed using the NIS-Elements D imaging software and images were captured on the Nikon Eclipse 80i light equipped with Nikon DS-Fi1 compound microscope (Nikon, Japan). The presence of phenolic compounds was also tested using autofluorescence (330 and $380 \mathrm{~nm}$ ) [62].

\subsection{Fluorescence Microscopy}

Semi-thin $(80-100 \mu \mathrm{m})$ young leaf and stem sections were viewed at various wavelengths with a Nikon DS-Fi1 compound microscope (Nikon, Japan) equipped with NIS Elements D software. The sections were stained with Acridine orange and $0.01 \%$ Calcofluor white solution to detect the viability of cells and cellulose in cell walls, respectively [52].

\subsection{Whole Mount Staining}

Whole seedling leaves were fixed for $24 \mathrm{~h}$ at $4{ }^{\circ} \mathrm{C}$ in a solution of formalin, acetic acid and ethanol (3.5:10:50). The samples were washed with 70\% ethanol and stained with Sudan Black B $(0.1 \%)$ in $70 \%$ ethanol for $3-4 \mathrm{~h}$ at $23{ }^{\circ} \mathrm{C}$. The samples were rinsed with $70 \%$ ethanol, distilled water and placed in $2.5 \mathrm{M} \mathrm{NaOH}$ solution until the leaves were cleared [33]. The samples were mounted onto a slide and the entire leaf was examined using the NIS-Elements D imaging software. Images were captured on the Nikon Eclipse 80i light compound microscope (Nikon, Japan).

\section{Conclusions}

The study concludes for the first time, the type and distribution of laticifers in the embryos, seedlings, and adult plants of T. ventricosa, and the plausible functions of laticifers and latex within this species. The ontogenetic studies of Tabernaemontana ventricosa confirmed the presence of articulated anastomosing laticifers. The laticifers were found to have originated from ground meristematic tissue and procambium cells, where they eventually dispense into all ground and vascular tissue. The complex branching patterns of laticifers usually develop into a composite system comprised of " $\mathrm{Y}$ ", " $\mathrm{H}$ ", or "U"conformations. The latter observations are consistent with literature, since recently majority of the laticifers belonging to the Apocynaceae are often classified as articulated. In addition, histochemical analyses revealed a variety of secondary metabolites including carboxylated polysaccharides, lipophilic and hydrophilic substances, proteins, phenolics, terpenoids, neutral lipids, alkaloids, mucilage, pectin, resin acids, and acidic substances present in the laticifers of $T$. ventricosa. Considering the chemical composition of the latex present in the lumen of laticifers, it is suggested that the latex is used as a protective mechanism against herbivory. Furthermore, the presence of alkaloids within the latex highlights its potential therapeutic value for the treatment of various ailments.

Author Contributions: Conceptualization, methodology, C.N. and Y.N.; investigation and data curation, C.N. and Y.N.; validation, C.N., Y.N. and Y.H.D.; writing—original draft preparation, C.N.; writing—review and editing, 
C.N., Y.N. and Y.H.D.; supervision, Y.N. and Y.H.D.; funding acquisition, Y.N. and Y.H.D. All authors have read and agreed to the published version of the manuscript.

Funding: Authors extend their appreciation to the National Research Foundation, South Africa, (118 898), the International Scientific Partnership Program (ISPP\#0064) at King Saud University, and the University of KwaZulu-Natal (Westville Campus) for funding this research.

Acknowledgments: We gratefully acknowledge Vishal Bharuth, Subashen Naidu and Phillip Christopher from the Microscopy and Microanalysis Unit at the University of KwaZulu-Natal, Westville for their assistance with the microscopy components of the research. In addition, we show great gratitude towards Nneka Akwu for her editorial skills with this manuscript.

Conflicts of Interest: The authors declare no conflict of interest.

\section{References}

1. Evert, R.F. Esau's Plant Anatomy, 3rd ed.; Wiley-Interscience: New York, NY, USA, 2006; pp. $483-495$.

2. Castelblanque, L.; Balaguer, B.; Marti, C.; Rodríguez, J.J.; Orozco, M.; Vera, P. Multiple facets of laticifer cells. Plant Signal. Behav. 2017, 12, e1300743. [CrossRef]

3. Castelblanque, L.; Balaguer, B.; Marti, C.; Rodriguez, J.J.; Orozco, M.; Vera, P. Novel Insights into the Organization of Laticifer Cells: A Cell Comprising a Unified Whole System. Plant Physiol. 2016, 172, 1032-1044. [CrossRef] [PubMed]

4. Dussourd, D.; Eisner, T. Vein-cutting behavior: Insect counterploy to the latex defense of plants. Science 1987, 237, 898-901. [CrossRef] [PubMed]

5. Bauer, G.; Gorb, S.N.; Klein, M.-C.; Nellesen, A.; Von Tapavicza, M.; Speck, T. Comparative Study on Plant Latex Particles and Latex Coagulation in Ficus benjamina, Campanula glomerata and Three Euphorbia species. PLoS ONE 2014, 9, e113336. [CrossRef] [PubMed]

6. Shih, M.-L.; A Morgan, J. Metabolic flux analysis of secondary metabolism in plants. Metab. Eng. Commun. 2020, 10, e00123. [CrossRef]

7. Tiwari, P.; Sangwan, N.S.; Sangwan, N.S. Plant secondary metabolism linked glycosyltransferases: An update on expanding knowledge and scopes. Biotechnol. Adv. 2016, 34, 714-739. [CrossRef]

8. Pott, D.M.; Osorio, S.; Vallarino, J. From Central to Specialized Metabolism: An Overview of Some Secondary Compounds Derived from the Primary Metabolism for Their Role in Conferring Nutritional and Organoleptic Characteristics to Fruit. Front. Plant Sci. 2019, 10, 835. [CrossRef]

9. Aharoni, A.; Galili, G. Metabolic engineering of the plant primary-secondary metabolism interface. Curr. Opin. Biotechnol. 2011, 22, 239-244. [CrossRef]

10. Wink, M. Introduction: Biochemistry, Physiology and Ecological Functions of Secondary Metabolites. Biochem. Plant Second. Metab. 2010, 40, 1-19. [CrossRef]

11. Esau, K. Plant Anatomy, 3rd ed.; McGraw-Hill: New York, NY, USA, 1965; pp. 483-490.

12. Metcalfe, C.R. Distribution of latex in the plant kingdom. Econ. Bot. 1967, 21, 115-127. [CrossRef]

13. Pickard, W.F. Laticifers and secretory ducts: Two other tube systems in plants. New Phytol. 2008, 177, 877-888. [CrossRef] [PubMed]

14. Ramos, M.V.; Demarco, D.; Souza, I.C.D.C.; De Freitas, C.D.T. Laticifers, Latex, and Their Role in Plant Defense. Trends Plant Sci. 2019, 24, 553-567. [CrossRef] [PubMed]

15. Fahn, A. Functions and location of secretory tissues in plants and their possible evolutionary trends. Isr. J. Plant Sci. 2002, 50, 302. [CrossRef]

16. Hagel, J.M.; Yeung, E.C.; Facchini, P.J. Got milk? The secret life of laticifers. Trends Plant Sci. 2008, 13, 631-639. [CrossRef]

17. Mahlberg, P.G. Laticifers: An historical perspective. Bot. Rev. 1993, 59, 1-23. [CrossRef]

18. Canaveze, Y.; Machado, S.R. The Occurrence of Intrusive Growth Associated with Articulated Laticifers in Tabernaemontana catharinensis A.DC., a New Record for Apocynaceae. Int. J. Plant Sci. 2016, 177, 458-467. [CrossRef]

19. Krishnamurthy, K.V.; Venkatasubramanian, P.; Lalitha, S.; Bahadur, B.; Sujatha, M.; Carels, N. Laticifers of Jatropha. In Jatropha; Challenges for a New Energy crop; Springer: New York, NY, USA, 2013; Volume 2, pp. 3-10. [CrossRef]

20. Demarco, D.; Castro, M.D.M. Laticíferos articulados anastomosados em espécies de Asclepiadeae (Asclepiadoideae, Apocynaceae) e suas implicações ecológicas. Braz. J. Bot. 2008, 31, 701-713. [CrossRef] 
21. Canaveze, Y.; Machado, S.R. Leaf colleters in Tabernaemontana catharinensis (Apocynaceae, Rauvolfioideae): Structure, ontogenesis, and cellular secretion. Botany 2015, 93, 287-296. [CrossRef]

22. Leeuwenberg, A.J.M.; Kupicha, F.K. Apocynaceae; Launert, E., Ed.; Flora Zambesiana: London, UK, 1985; pp. 395-503.

23. Schmelzer, G.B.; Gurib-Fakim, A. Medicinal Plants; plant resources of tropical Africa PROTA Foundation, 1st ed.; Backhuys Publishers: Wageningen, The Netherlands, 2008; Volume 1, pp. 597-598.

24. Schmidt, E.; Lotter, M.; McCleland, W. Trees and Shrubs of Mpumalanga and Kruger National Park; Illustrated, Ed.; Jacana Media: Johannesburg, South Africa, 2002; pp. 566-569.

25. Mehrbod, P.; Abdalla, M.; Njoya, E.M.; Ahmed, A.S.; Fotouhi, F.; Farahmand, B.; Gado, D.; Tabatabaian, M.; Fasanmi, O.; Jn, E.; et al. South African medicinal plant extracts active against influenza A virus. BMC Complement. Altern. Med. 2018, 18, 112. [CrossRef]

26. Hanley, M.E.; Lamont, B.; Fairbanks, M.M.; Rafferty, C. Plant structural traits and their role in anti-herbivore defence. Perspect. Plant Ecol. Evol. Syst. 2007, 8, 157-178. [CrossRef]

27. Konno, K. Plant latex and other exudates as plant defence systems: Roles of various defence chemicals and proteins contained therein. Phytochemistry 2011, 72, 1510-1530. [CrossRef] [PubMed]

28. Agrawal, A.A.; Konno, K. Latex: A model for understanding mechanisms, ecology, and evolution of plant defence against herbivory. Annu. Rev. Ecol. Evol. Syst. 2009, 40, 311-331. [CrossRef]

29. Lopes, K.L.B.; Thadeo, M.; Azevedo, A.A.; Soares, A.A.; Meira, R.M.S.A. Articulated laticifers in the vegetative organs of Mandevilla atroviolacea (Apocynaceae, Apocynoideae). Botany. 2009, 87, 202-209. [CrossRef]

30. Pirolla-Souza, A.; Arruda, R.C.O.; Pace, M.R.; Farinaccio, M.A. Leaf anatomical characters of Rhabdadenia (Rhabdadenieae, Apocynaceae), their taxonomic implications, and notes on the presence of articulated laticifers in the genus. Plant Syst. Evol. 2019, 305, 797-810. [CrossRef]

31. Gama, T.D.S.S.; Rubiano, V.S.; Demarco, D. Laticifer development and its growth mode in Allamanda blanchetii A. DC. (Apocynaceae). J. Torrey Bot. Soc. 2017, 144, 303-312. [CrossRef]

32. Serpe, M.D.; Muir, A.; Driouich, A. Immunolocalization of $\beta$-D-glucans, pectins, and arabinogalactan-proteins during intrusive growth and elongation of nonarticulated laticifers in Asclepias speciosa Torr. Planta 2002, 215, 357-370. [CrossRef]

33. Demarco, D.; Castro, M.D.M.; Ascensão, L. Two laticifer systems in Sapium haematospermum—New records for Euphorbiaceae. Botany 2013, 91, 545-554. [CrossRef]

34. Marinho, C.; Teixeira, S.P. Novel reports of laticifers in Moraceae and Urticaceae: Revisiting synapomorphies. Plant Syst. Evol. 2018, 305, 13-31. [CrossRef]

35. Fineran, B.A. Distribution and Organization of Non-articulated Laticifers in Mature Tissues of Poinsettia (Euphorbia pulcherrima Willd.). Ann. Bot. 1982, 50, 207-220. [CrossRef]

36. Rudall, P. Laticifers in Crotonoideae (Euphorbiaceae): Homology and Evolution. Ann. Missouri Bot. Gard. 1994, 81, 270. [CrossRef]

37. Kumar, G.; Karthik, L.; Rao, K.V.B. A review on pharmacological and phytochemical profile of Calotropis gigantea Linn. Pharmacol. Online 2011, 1, 1-8.

38. Nazar, N.; Goyder, D.J.; Clarkson, J.J.; Mahmood, T.; Chase, M.W. The taxonomy and systematics of Apocynaceae: Where we stand in 2012. Bot. J. Linn. Soc. 2013, 171, 482-490. [CrossRef]

39. Rapini, A.; Chase, M.W.; Goyder, D.J.; Griffiths, J.; Vanderpoorten, A.; Żarnowiec, J. Asclepiadeae classification: Evaluating the phylogenetic relationships of New World Asclepiadoideae (Apocynaceae). TAXON 2003, 52, 33-50. [CrossRef]

40. Gonçalves, M.P.; Mercadante-Simões, M.O.; Ribeiro, L.M. Ontogeny of anastomosed laticifers in the stem apex of Hancornia speciosa (Apocynaceae): A topographic approach. Protoplasma 2018, 255, 1713-1724. [CrossRef]

41. De, M.C.M.; Demarco, D. Phenolic Compounds Produced by Secretory Structures in Plants: A Brief Review. Nat. Prod. Commun. 2008, 3, 1273-1284. [CrossRef]

42. Silveira, D.; De Melo, A.F.; Magalhães, P.; Fonseca, Y. Tabernaemontana Species: Promising Sources of New Useful Drugs. In Bioactive Natural Products; Elsevier BV: Amsterdam, The Netherlands, 2017; Volume 54, pp. 227-289.

43. Van Beek, T.; Verpoorte, R.; Svendsen, A.; Leeuwenberg, A.; Bisset, N. Tabernaemontana L. (Apocynaceae): A review of its taxonomy, phytochemistry, ethnobotany and pharmacology. J. Ethnopharmacol. 1984, 10, 1-156. [CrossRef] 
44. Marinho, F.F.; Simões, A.O.; Barcellos, T.; Moura, S. Brazilian Tabernaemontana genus: Indole alkaloids and phytochemical activities. Fitoterapia 2016, 114, 127-137. [CrossRef]

45. Athipornchai, A. A Review on Tabernaemontana spp.: Multipotential Medicinal Plant. Asian J. Pharm. Clin. Res. 2018, 11, 45-53. [CrossRef]

46. Schripsema, J.; Hermans-Lokkerbol, A.; Van Der Heijden, R.; Verpoorte, R.; Svendsen, A.B.; Van Beek, T.A. Alkaloids of Tabernaemontana ventricosa. J. Nat. Prod. 1986, 49, 733-735. [CrossRef]

47. Pallant, C.; Cromarty, A.; Steenkamp, V.; Cromarty, A.D. Effect of an alkaloidal fraction of Tabernaemontana elegans (Stapf.) on selected micro-organisms. J. Ethnopharmacol. 2012, 140, 398-404. [CrossRef]

48. Mahlberg, P.G.; Davis, D.G.; Galitz, D.S.; Manners, G.D. Laticifers and the classification of Euphorbia: The chemotaxonomy of Euphorbia esula L. Bot. J. Linn. Soc. 1987, 94, 165-180. [CrossRef]

49. Farrell, B.D.; Dussourd, D.E.; Mitter, C. Escalation of Plant Defense: Do Latex and Resin Canals Spur Plant Diversification? Am. Nat. 1991, 138, 881-900. [CrossRef]

50. Pereira, C.G.; Marques, M.; Barreto, A.S.; Siani, A.C.; Fernandes, E.C.; Meireles, M.A. Extraction of indole alkaloids from Tabernaemontana catharinensis using supercritical $\mathrm{CO}_{2+}$ ethanol: An evaluation of the process variables and the raw material origin. J. Supercrit. Fluids 2004, 30, 51-61. [CrossRef]

51. Thombre, R.; Jagtap, R.; Patil, N. Evaluation of phytoconstituents, anti-bacterial, anti-oxidant and cytotoxic activity of Vitex negundo L. and Tabernaemontana divaricata L. Int. J. Pharma. Bio. Sci. 2013, 4, 389-396.

52. Demarco, D. Histochemical Analysis of Plant Secretory Structures; Humana Press: New York, NY, USA, 2017; pp. 31-330. [CrossRef]

53. Wilson, K.J.; Mahlberg, P.G. Ultrastructure of non-articulated laticifers in mature embryos and seedlings of Asclepias syriaca L (Asclepiadaceae). Am. J. Bot. 1978, 65, 98-109. [CrossRef]

54. Wilson, K.J.; Mahlberg, P.G. Ultrastructure of developing and mature non-articulated laticifers in the milkweed Asclepias syriaca L. (Asclepiadaceae). Am. J. Bot. 1980, 67, 1160-1170. [CrossRef]

55. Roy, A.T.; De, D.N. Studies on Differentiation of Laticifers through Light and Electron Microscopy in Calotropis gigantea (Linn.) R.Br. Ann. Bot. 1992, 70, 443-449. [CrossRef]

56. Demarco, D. Micromorfolog1'a y histoquı́mica de los latic1 'feros de' organos vegetativos de especies de Asclepiadoideae (Apocynaceae). Acta Biol. Colomb. 2015, 20, 57-65. [CrossRef]

57. O'Brien, T.P.; Feder, N.; McCully, M.E. Polychromatic staining of plant cell walls by toluidine blue O. Protoplasma 1964, 59, 368-373. [CrossRef]

58. McCracken, E.; Johansen, D.A. Plant Microtechnique. Trans. Am. Microsc. Soc. 1940, 59, 405. [CrossRef]

59. Mazia, D.; Brewer, P.A.; Alfert, M. The cytochemical staining and measurement of protein with mercuric bromphenol blue. Boil. Bull. 1953, 104, 57-67. [CrossRef]

60. Furr, M.; Mahlberg, P.G. Histochemical Analyses of Laticifers and Glandular Trichomes in Cannabis sativa. J. Nat. Prod. 1981, 44, 153-159. [CrossRef]

61. Periasamy, K. A technique of staining sections of paraffin-embedded plant materials without employing a graded ethanol series. J. R. Microsc. Soc. 1967, 87, 109-112. [CrossRef] [PubMed]

62. Ascensão, L.; Pais, M.S.S. Glandular Trichomes of Artemisia campestris (ssp. Maritima): Ontogeny and Histochemistry of the Secretory Product. Int. J. Plant Sci. 1987, 148, 221-227. [CrossRef]

(C) 2020 by the authors. Licensee MDPI, Basel, Switzerland. This article is an open access article distributed under the terms and conditions of the Creative Commons Attribution (CC BY) license (http://creativecommons.org/licenses/by/4.0/). 